\title{
Replacement of raw soybean with roasted soybean increased milk production in Holstein cows
}

\author{
Gilson Sebastião Dias Júnior ${ }^{1}$ Vítor Augusto Silveira $^{1}$ Ivan Júnior Ascari $^{1}$ \\ Renata Apocalypse Nogueira Pereira ${ }^{2}$ Marina de Arruda Camargo Danés ${ }^{1}$ Marcos Neves Pereira ${ }^{1 *}$
}

'Departamento de Zootecnia, Universidade Federal de Lavras (UFLA), 37200-000, Lavras, MG, Brasil. E-mail: mpereira@dzo.ufla.br ${ }^{*}$ Corresponding author.

${ }^{2}$ Empresa de Pesquisa Agropecuária de Minas Gerais (EPAMIG), Lavras, MG, Brasil.

ABSTRACT: The aim of this study was to evaluate the effect of total replacement of raw whole soybean (RAW) for roastedwhole soybean (ROS) on the production performance of Holstein cows. Two experiments were carried out usinga simple reversal design where RAW has been completely replaced by ROS. In experiment 1, 22 cows (175 60 days in milk)were used, and the dietary inclusion level of RAW or ROS was 3.7\%

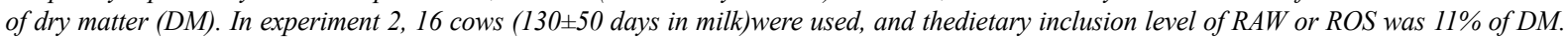
In both experiments, ROS increased milk production by $1.1 \mathrm{kgday}^{-1}$ without changing fat and protein production. Dry matter intake or milk urea nitrogenwere not affected by dietary soy source. In experiment 2, plasma glucose concentration was decreased, and allantoin/creatinine ratio in urine tended to decreasein ROS. Experiment 2 also evaluated the nutrient digestibility and ruminal degradation kinetics of crude protein in two soybean sources. Roasting had no effect on the digestibility of DM, organic matter, and neutral detergent fiber. Roasted whole soybean hadgreater fraction $B$ and lower protein degradation rate than did $R A W$; this showed that heat treatment was effective in increasing therumen undegradable amino acid flowto the animal, which suggesteda potential mechanism of action for improved performance observed in ROS. Key words: non-degradable protein, roasting, milk production.

Substituição de soja crua por soja tostada aumentou a produção de leite em vacas da raça Holandesa

RESUMO: O objetivo deste estudo foi avaliar o efeito da substituição total de soja integral crua (SC) por soja integral tostada (ST) sobre o desempenho produtivo de vacas Holandês. Foram realizados dois experimentos com delineamento experimental de reversão simples nos quais a SC foi totalmente substituida por ST. No experimento 1, foram utilizadas 22 vacas (175 $\pm 60 D E L)$ e o nível de inclusão dietética de SC ou ST foi de 3,7\% na matéria seca (MS). No experimento 2, foram utilizadas 16 vacas (130 \pm 50 DEL) e o nível de inclusão dietético de SC ou ST foi de 11\% na MS. Em ambos os experimentos, ST aumentou a produção de leite em 1,1 $\mathrm{kgd}^{-1}$, sem alterar as produções de gordura e proteina. O consumo de MS e nitrogênio uréico no leite não foram afetados pela fonte de soja dietética. No experimento 2, a concentração de glicose plasmática foi reduzida e a relação alantoína/creatinina na urina tendeu a ser reduzida por ST. O experimento 2 também avaliou digestibilidade de nutrientes e cinética de degradação ruminal da proteína bruta das duas fontes de soja. Não houve efeito da tostagem nas digestibilidades da MS, matéria orgânica e FDN. A ST apresentou maior fração B e menor taxa de degradação da proteína do que a SC, mostrando que o tratamento térmico foi efetivo em aumentar o fluxo de aminoácidosnão degradáveis no rúmen para o animal, sugerindo um potencial mecanismo de ação para a melhora no desempenho observada com ST.

Palavras-chave: proteína não degradável no rúmen, tostagem, podução de leite.

\section{INTRODUCTION}

Soy is the main source of true protein for dairy cows in Brazil and is mainly in the form of soybean meal, which features high ruminal degradability (around $65 \%$ crude protein $(\mathrm{CP})$ ). This fact, coupled with the prohibition ofusing protein sources of animal origin, limits the formulation of diets rich in rumen undegradable protein (RUP). The replacement of proteinaceous food by high ruminal degradability foods rich in RUPmight increase the metabolizable amino acid flow to the animal
(NRC, 2001). Heat treatment of whole soybean is an alternative for reducing protein degradability (ABDI et al., 2013).

However, results presented in the literature regarding the responses in farm animals fed withheattreated soy diets are conflicting. Studies have shown that the substitution of raw soybean (RAW) by roasted soybean (ROS) is responsible for increasing milk production (FALDET \& SATTER, 1991; FATHI NASRI et al., 2007), which emphasizedthe importance of raising the dietary content of RUP. Roasted whole soybean can supply dietary amino 
acids in non-degradable form in the rumen, which can stimulate milk production (FALDET \& SATTER, 1991). However, others studies on the replacement of RAW for ROS did not affect milk production (AMANLOU et al., 2012; ABDI et al., 2013).

Differences in responses in production reported in the literature can be attributed to several factors such as lactation stage and milk production rate (FATHI NASRI et al., 2007). Furthermore, the efficiency of the roasting process as a means of reducing protein degradability in soybean depends on the time and processing temperature. Excessive heat treatment can reduce protein digestibility and the availability of certain amino acids in the small intestine (SCOTT et al., 1991; FATHI NASRI et al., 2008). Thus, it is important to determine the ruminal degradability of protein in foods subjected to heat treatment. However, it is possible to observe a low numberof studies with regard tothe efficiency ofthe roasting process in ruminal degradability. In addition, there are no reports in the literature evaluating the use of ROS in low dietary inclusion levels.

The objective of the present study was to evaluate the replacement of RAW for ROS on two dietary inclusion levels on the production performance of dairy cows. In addition, it aimed to investigate the ruminal degradation kinetics of protein from two soybean sources to evaluate the effectiveness of heat treatment in increasing RUP flow. The hypothesis is that the replacement of RAW for ROS improves the production performance of dairy cows due to an increase in rumen undegradable amino acid flow to the animal.

\section{MATERIALS AND METHODS}

The experiments were performed at the Better Nature Research Center (Ijaci, Minas Gerais, Brazil) where the animals were housed in a "tie-stall" barn with ad libitum access to water. In experiment 1 , 22 Holstein cows ( $175 \pm 60$ days in milk) were paired based on calving order and milk yield and randomly assigned to a treatment sequencedelineating simple reversal design with two periods of 13 days and 10 days to adapt to treatment.

The complete diet (Table 1) was offered twice daily at approximately $06: 00$ and 14:00h in amounts to provide $10.0 \%$ orts (as-fed basis). Dry matter (DM) content (oven-drying at $105^{\circ} \mathrm{C}$ ) of corn silage was monitored weekly to adjust the proportion of fresh ingredients and to ensure the constant composition of ingredients (\% DM) of the diet.

The two treatments consisted of the inclusion of $3.7 \%$ of DM offered daily from RAW or
ROS. Both soy sources (Alfa Nutrisoja, Cooperalfa, Chapecó, Brazil) originated from the same lot differing only in heat treatment. In the roasting process, steam injection was used $\left(125^{\circ} \mathrm{C}\right.$ for 10 to $15 \mathrm{~min}$ and $2 \mathrm{kgf} \mathrm{cm}^{-2}$ ). Raw soybeans were processed in a fodder disintegrator without sieves.

Individual cow intake was calculated between 11 and 13 days, by recording the amount of feed offered and orts (as-fed basis). Samples of ingredients and orts were collected daily, stored at $-20^{\circ} \mathrm{C}$, and a compound period was formed from equal amounts of each daily sample. Composite samples were dried in forced-air oven at $55^{\circ} \mathrm{C}$ for $72 \mathrm{~h}$ and ground through a 1-mm screen in a Wiley mill (A.H. Thomas, Philadelphia, PA). The DM content was determined by drying at $100^{\circ} \mathrm{C}$ for $24 \mathrm{~h}$ and $\mathrm{CP}$ was determined by micro-Kjeldahl analysis (AOAC, 1990). Ether extract was analyzed according to AOAC (1990). Ash was analyzed by incineration at $550^{\circ} \mathrm{C}$ for $8 \mathrm{~h}$. The NDF was analyzed using a TE149 fiber analyzer (Tecnal Equipamentos, Piracicaba, Brazil) with amylase and sodium sulfide.

Individual daily milk yield was recorded between 11 and 13 days, and a daily sample was obtained from the three milking collected in proportion to the production of each milking. These samples were placed in vials with bronopol to determine the fat, protein, lactose, and total solidcontent (APCBRH, Curitiba, Brazil), through optical and infrared systems(Bentley 2000, Bentley Instruments Inc., Chaska, MN). The analysis of milk urea nitrogen (MUN) concentration was performed (Chemspec 150 - Bentley Instruments ${ }^{\circledR}$ ) using the Berthelot method (BERGMEYER, 1985). Milk energy secretion (MilkE, Mcalday ${ }^{-1}$ ) was calculated as $[(0.0929 \times \%$ fat $)+(0.0547 \times \%$ protein $)+(0.0395$ $\times \%$ lactose $)] \times \mathrm{kg}$ of milk (NRC, 2001). Energy corrected milk (ECM, kgday $\left.{ }^{-1}\right)$ was calculated as $\mathrm{ECM}=\mathrm{MilkE} / 0.70$ (assumes $0.70 \mathrm{Mcalkg}^{-1}$ for milk with $3.7 \%$ fat, $3.2 \%$ protein, and $4.6 \%$ lactose).

In experiment 2, 16 Holstein cows (130 \pm 50 days in milk) were paired based on calving order and milk yield, and randomly assigned to a treatment sequence delineating simple reversal design with two periods of 21 days and 14 days to adapt to treatment. Treatments were the same as in experiment 1 with the exception of dietary inclusion level of RAW or ROS, which was 11\% of DM (Table 1). Diets were offered at 07:00 and 15:00h in amounts to provide $10.0 \%$ orts (as-fed basis).

Individual cow intake was calculated between 16 and 20 days of each period, by recording the amount of feed offered and orts (as-fed basis). Collections of 
Table 1 - Composition of diets offered in ingredients, and consumed diets in nutrients (\% dry matter) in raw soybean (RAW) and roasted soybean (ROS) treatments (Experiments 1 and 2).

\begin{tabular}{|c|c|c|c|c|}
\hline & \multicolumn{2}{|c|}{------------Experiment 1------------ } & \multicolumn{2}{|c|}{------------Experiment 2----------- } \\
\hline & RAW & ROS & RAW & ROS \\
\hline Corn silage & 47.7 & 47.7 & 46.9 & 46.9 \\
\hline Ground raw whole soybeans & 3.7 & - & 11.0 & - \\
\hline $\begin{array}{l}\text { Ground roasted whole soybeans } \\
\text { coarsely ground roasted whole soybeans }\end{array}$ & - & 3.7 & - & 10.9 \\
\hline Finely ground corn & 16.0 & 16.0 & 10.7 & 10.7 \\
\hline Soybean meal & 16.9 & 16.9 & 13.0 & 13.0 \\
\hline Citrus pulp & 12.3 & 12.3 & 16.2 & 16.2 \\
\hline $\mathrm{HMBi}^{1}$ & 0.12 & 0.12 & - & - \\
\hline Urea & 0.4 & 0.4 & - & - \\
\hline Magnesium oxide & 0.2 & 0.2 & - & - \\
\hline Sodium bicarbonate & 0.8 & 0.8 & 1.3 & 1.3 \\
\hline Salt & 0.3 & 0.3 & - & - \\
\hline Limestone & 1.3 & 1.3 & - & - \\
\hline Minerals and vitamins ${ }^{2}$ & 0.3 & 0.3 & - & - \\
\hline Minerals and vitamins ${ }^{3}$ & - & - & 1.0 & 1.0 \\
\hline \multicolumn{5}{|c|}{----1 } \\
\hline $\mathrm{CP}$ & 17.6 & 17.7 & 15.9 & 16.3 \\
\hline NDF & 35.0 & 34.9 & 36.4 & 37.3 \\
\hline Ether extract & 4.9 & 4.8 & 5.1 & 5.3 \\
\hline Ash & 8.5 & 8.5 & 6.0 & 6.1 \\
\hline Non fiber carbohydrates ${ }^{4}$ & 34.0 & 34.1 & 36.5 & 34.7 \\
\hline
\end{tabular}

${ }^{1}$ 2-hydroxy-4-(methylthio) butanoic acid (Metasmart, Adisseo Inc., Antony,France) ${ }^{2} 20.0 \% \mathrm{Ca} ; 15.0 \% \mathrm{P} ; 3.0 \% \mathrm{~S} ; 3.0 \% \mathrm{Mg} ; 100 \mathrm{mgkg}{ }^{-1}$ of $\mathrm{Co} ; 3,000 \mathrm{mgkg}^{-1}$ of $\mathrm{Cu} ; 180 \mathrm{mgkg}^{-1}$ of I; $3,000 \mathrm{mgkg}^{-1}$ of $\mathrm{Mn} ; 12,000 \mathrm{mgkg}^{-1}$ of Zn; $100,000 \mathrm{Ulkg}^{-1}$ of vitamin A; $250,000 \mathrm{UIkg}{ }^{-1}$ of vitamin $\mathrm{D}_{3} ; 6,250 \mathrm{Ulkg}^{-1}$ of vitamin E. ${ }^{3} 18.5 \%$ ofCa; $15.0 \%$ of P; $30.0 \%$ of S; $30.0 \%$ of Mg; $240 \mathrm{mgkg}^{-1}$ of Co; $3,000 \mathrm{mgkg}^{-1}$ of Cu; $180 \mathrm{mgkg}^{-1}$ of I; $8,000 \mathrm{mgkg}^{-1}$ of $\mathrm{Mn} ; 12,000 \mathrm{mgkg}^{-1}$ of $\mathrm{Zn} ; 90 \mathrm{mgkg}^{-1}$ of Se; $100,000 \mathrm{Ulkg}^{-1}$ of vitamin A; $250,000 \mathrm{Ulkg}^{-1}{\mathrm{of} \mathrm{vitamin} \mathrm{D}_{3} ; 6,250 \mathrm{UIkg}}^{-1} \mathrm{of}^{2}$ vitamin $\mathrm{E} .{ }^{4} \mathrm{NCF}=100-(\mathrm{CP}+\mathrm{NDF}+\mathrm{EE}+\mathrm{Ash})$.

samples and their analysis were performed in the same way as already described in experiment 1 .

Cows were milked three times a day under the same conditions and time of the experiment 1 . Milk yield was measured on the same days of the assessment of consumption. Milk samples of six consecutive milking collected between 17 and 19 days were used to determine the total solids content and MUN (APCBRH) as procedures in experiment 1.

Total-tract apparent digestibility of DM, organic matter, NDF, and non-NDF organic matter was determined by total collection of feces performed in three periods of eight uninterrupted hours between 18 and 20 days of each experimental period (SALVATI et al., 2015). To obtain a representative sample of
$24 \mathrm{~h}$ without disturbing feed intake and milk yield, sampling started $8 \mathrm{~h}$ later in relation to the collection done on the previous day. Uniform fecal samples from each cow were continuously frozen along each collection day to yield a composite sample at the end of each period. Fecal composite samples were oven dried at $55^{\circ} \mathrm{C}$ for $72 \mathrm{~h}$ and NDF and ash contents were determined according to the methodology described in experiment 1. Daily intake of digestible organic matter was calculated by multiplying the consumption of organic matter measured between 16 and 20 days by the coefficient of digestibility of organic matter measured between 18 and 20 days.

Six urine samples from each cow were obtained concomitantly with collection of feces to 
estimate the relative microbial protein synthesis in the rumen. Each urine subsample was immediately acidified with $2 \%$ ( $\mathrm{vol} / \mathrm{vol}$ ) sulfuric acid at $20 \%$ concentration and stored at $4{ }^{\circ} \mathrm{C}$ until the end of the collection period when a sample from each cow was formed with equal proportions of each subsample. Composite urine samples were diluted 1:4 (urine/water) with distilled water and frozen at $-20^{\circ} \mathrm{C}$. Allantoin was performed as described by CHEN \& GOMES (1995), and a commercial kit (Labtestdiagnostica S.A., Lagoa Santa, Brazil) was used for the determination of creatinine. Relationship between urinary allantoin and creatinine was used to estimate microbial protein flow to the intestine.

On the $20^{\text {th }}$ day of each experimental period, blood samples were collected from the coccygeal vessels $12 \mathrm{~h}$ after the morning feeding in order to assess plasma glucose concentration. Blood was collected in tubes a tubes containing potassium fluoride, centrifuged at $1,000 \times \mathrm{g}$ for $15 \mathrm{~min}$, and the obtained plasma was frozen at $-20^{\circ} \mathrm{C}$ until analysis of glucose using a commercial kit (Labtest Diagnóstica S.A., Lagoa Santa, Brazil).

The protein degradability of RAW and ROS was evaluated in situ in three cows with rumen cannula. Five grams of pre-dried samples was placed in polyester bags $(9 \times 11 \mathrm{~cm})$ and incubated in triplicate in the rumen at $0,3,6,9,12,24$ and $72 \mathrm{~h}$. Considering that $\mathrm{R}$ is the protein mass on the residue after incubation and washing of the samples, and I is the initial mass of the sample, the protein fractions A, $\mathrm{B}$, and $\mathrm{C}$ were calculated as: A (instantly degraded fraction $)=(\mathrm{I}-\mathrm{R}$ of time 0$) / \mathrm{I} ; \mathrm{C}$ (indigestible fraction) $=\mathrm{R}$ at time $72 / \mathrm{I} ; \mathrm{B}$ (slowly degrades fraction) $=100$ - $(\mathrm{A}+\mathrm{C})$. The fractional degradation rate of fraction $\mathrm{B}(\mathrm{Kd})$ was estimated over time as the slope of the linear regression of the natural logarithm of the residues as a percentage of sample initially incubated after subtracting the fraction $\mathrm{C}$ values.

Data of the experiments1 and 2 were analyzed using the PROC GLM of SAS (9.1, Cary, $\mathrm{NC}$, USA). The model used for the analysis: $\mathrm{Y}_{\mathrm{ijkl}}=$ $\mu+\mathrm{B}_{\mathrm{i}}+\mathrm{V}_{\mathrm{j}(\mathrm{i})}+\mathrm{P}_{\mathrm{k}}+\mathrm{T}_{1}+e_{\mathrm{ijkl} .}$; where: $\mathrm{Y}_{\mathrm{ijk}}=$ dependent variable; $\mu=$ overall mean; $\mathrm{B}_{\mathrm{i}}=$ block effect $(\mathrm{i}=1$, $2 \ldots 11$ in exp. $1 ; \mathrm{i}=1,2 \ldots 8$ in exp. 2$) ; \mathrm{V}_{\mathrm{j}(\mathrm{i})}=$ cow effect within block $(j=1,2 \ldots 22$ in exp. $1 ; j=1, \ldots 16$ in exp. 2); $\mathrm{P}_{\mathrm{k}}=$ period effect $(\mathrm{k}=1$ or 2$) ; \mathrm{T}_{1}=$ effect of the treatment $(1=\mathrm{RAW}$ and ROS $) ; e_{\mathrm{ijkl}}=$ experimental error, independent, with normal distribution, mean zero and variance $\sigma^{2}$. Data of the degradability testwere analyzed using the PROC GLM. The model used for the analysis: $\mathrm{Y}_{\mathrm{ij}}=\mu+\mathrm{A}_{\mathrm{i}}+\mathrm{T}_{\mathrm{j}}+e_{\mathrm{ij}}$; where: $\mathrm{Y}_{\mathrm{ij}}=$ dependent variable; $\mu=$ overall mean; $A_{i}=$ animal effect ( $i=1,2$ and 3$) ; T_{j}=$ effect of the treatment $(\mathrm{j}=\mathrm{RAW}$ and ROS $) ; e_{\mathrm{ijkl}}=$ experimental error, independent, with normal distribution, mean zero and variance $\sigma^{2}$. Statistical significance and trends were considered at $P \leq 0.05$ and $P>0.05$ to $P \leq 0.10$, respectively.

\section{RESULTS AND DISCUSSION}

Consumption of DM (experiments 1 and 2, table 2) or digestible organic matterwas not affected by the treatments (experiment 2, table 2). Similarly, FALDET \& SATTER (1991) reported no difference in dry matter intake (DMI) when comparing raw or roastedisonitrogen soy diets provided for dairy cows with alfalfa silage as the only forage.

The substitution of RAW by ROS in both dietary inclusion levels (3.7 and $10.9 \%$ of DM) promoted a positive response in milk performance (Table 2) with increments in daily secretions of milk $\left(1.1 \mathrm{kgday}^{-1}\right)$ and lactose $\left(0.06 \mathrm{kgday}^{-1}\right)$. Furthermore, the production of solids increased in experiment 1 and tended to increase in experiment 2, and milk yield corrected for energy tended to increase in experiment 1 with ROS treatment.The response in performance to roasted soybean is variable. With the inclusion of $13 \%$ of DM in diets, FALDET \& SATTER (1991) reported an increase of $4.5 \mathrm{kgday}^{-1}$ in milk yield with ROS replacing RAW. However, in other studies, responses were not observed with the addition of roasted soybean in production (AMANLOU et al., 2012; ABDI et al., 2013).

The highest milk yield observed with ROS treatment in two experiments was related to their increased lactose production (Table 2). Stimulation of lactose production in response to increased protein availability in the intestine has been observed in several studies (LEMOSQUET et al., 2009; GALINDO et al., 2011), which suggested a possible mechanism of action related to an increased input of RUP in roasted soybean treatment. Amino acids are precursors in hepatic gluconeogenesis, and can increase glucose availability for lactose synthesis (LEMOSQUET et al., 2009).

An increased glucose intake from amino acid could be verified by an increase of plasma glucose inROS treatment, which was not observed in experiment 2 (Table 2). In fact, plasma glucose was decreased in the ROS treatment. The concentration of a metabolite in blood resultedfrom the production and absorption of intestinal processes vs. utilization by tissue cells. Roasted soybean treatment increased lactose production and tended to increase the 
Table 2 - Milk composition, performance (Experiment 1), production performance, milk solids, allantoin/creatinine ratio in urine and plasma glucose concentration in dairy cows fed with diets containing raw soybean (RAW) or roasted soybean (ROS) (Experiment 2).

\begin{tabular}{|c|c|c|c|c|c|c|c|c|}
\hline & \multicolumn{4}{|c|}{----------------Experiment 1---------------- } & \multicolumn{4}{|c|}{ 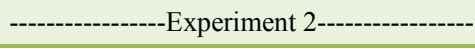 } \\
\hline & RAW & ROS & SEM & $P$ & RAW & ROS & SEM & $P$ \\
\hline DMI $\left(\operatorname{kgday}^{-1}\right)^{1}$ & 20.5 & 20.4 & 0.30 & 0.76 & 19.1 & 19.5 & 0.39 & 0.51 \\
\hline DOMI $\left(\text { kgday }^{-1}\right)^{2}$ & - & - & - & - & 13.3 & 13.2 & 0.31 & 0.80 \\
\hline Milk (kgday $\left.{ }^{-1}\right)$ & 30.8 & 31.9 & 0.32 & 0.03 & 29.1 & 30.2 & 0.40 & 0.05 \\
\hline ECM $\left(\text { kgday }^{-1}\right)^{3}$ & 28.0 & 29.1 & 0.47 & 0.09 & 27.3 & 28.4 & 0.52 & 0.18 \\
\hline Fat $\left(\operatorname{kgday}^{-1}\right)$ & 0.94 & 0.98 & 0.02 & 0.24 & 0.98 & 0.99 & 0.02 & 0.58 \\
\hline Protein $\left(\right.$ kgday $\left.^{-1}\right)$ & 0.96 & 0.98 & 0.01 & 0.11 & 0.89 & 0.91 & 0.01 & 0.22 \\
\hline Lactose $\left(\right.$ kgday $\left.^{-1}\right)$ & 1.42 & 1.48 & 0.02 & 0.01 & 1.33 & 1.39 & 0.02 & 0.03 \\
\hline Solids (kgday ${ }^{-1}$ ) & 3.61 & 3.76 & 0.05 & 0.04 & 3.19 & 3.29 & 0.07 & 0.08 \\
\hline Fat (\% no leite) & 3.07 & 3.13 & 0.06 & 0.55 & 3.38 & 3.30 & 0.05 & 0.30 \\
\hline Protein ( $\%$ in milk) & 3.15 & 3.12 & 0.01 & 0.09 & 3.06 & 3.04 & 0.02 & 0.33 \\
\hline Lactose ( $\%$ in milk) & 4.62 & 4.67 & 0.02 & 0.06 & 4.57 & 4.60 & 0.02 & 0.22 \\
\hline Solids (\%in milk) & 11.79 & 11.88 & 0.06 & 0.30 & 11.01 & 10.999 & 0.04 & 0.17 \\
\hline $\operatorname{MUN}\left(\mathrm{mgdL}^{-1}\right)^{4}$ & 14.9 & 15.1 & 0.31 & 0.65 & 11.9 & 11.9 & 0.28 & 0.84 \\
\hline $\operatorname{MilkE}\left(\text { Mcalday }^{-1}\right)^{5}$ & 19.6 & 20.4 & 0.30 & 0.09 & 19.2 & 19.7 & 0.27 & 0.18 \\
\hline Efficiency $\left(\mathrm{Mcalkg}^{-1}\right)^{6}$ & 0.96 & 1.01 & 0.02 & 0.09 & - & - & - & - \\
\hline Efficiency $\left(\mathrm{Mcalkg}^{-1}\right)^{7}$ & - & - & - & - & 1.49 & 1.50 & 0.03 & 0.21 \\
\hline Allantoin/creatinine ratio & - & - & - & - & 2.2 & 1.6 & 0.24 & 0.08 \\
\hline Plama glucose $\left(\mathrm{mgdL}^{-1}\right)$ & - & - & - & - & 54.8 & 51.4 & 0.90 & 0.01 \\
\hline
\end{tabular}

${ }^{1}$ Dry matter intake. ${ }^{2}$ Digestible Organic matter intake. ${ }^{3} \mathrm{ECM}=$ Energy corrected milk. ${ }^{4}$ Milk urea nitrogen. ${ }^{5}$ MilkE $=$ Milk energy secretion. ${ }^{6}$ Efficiency $=$ Milk energy/DMI. ${ }^{7}$ Efficiency $=$ Milk energy/DOMI.

production of solids (experiment 2) through processes that utilize glucose as a precursor or as an energy source and NADPH. Therefore, it is plausible to speculate that glucose extracted from the mammary gland was increased in the ROS treatment to meet this increased demand, thus reducing their plasma concentration (BOUTINAUD et al., 2008).

In addition to the effects related to glucose availability to the mammary gland, the largest amino acid supply can also act in intramammary metabolism altering metabolic pathways that prioritize lactose synthesis. LEMOSQUET et al. (2009) observed an increase in ratio between lactose secreted in milk and glucose extracted from the blood by the mammary gland in response to casein infusion in the duodenum accompanied by a decrease inplasma glucose concentration as observed in this study. When more glucose is targeted for lactose synthesis, the energy demand of the mammary gland must be supplied by other substrates such as $\beta$-hydroxybutyricacid (LEMOSQUET et al., 2009). The mechanism by which amino acids have caused this change of metabolic pathways is not understood but may be related to its own amino acids being oxidized and used as an energy source for the cell, which releases glucose for anabolic functions such as lactose synthesis (RAGGIO et al., 2006).

Increased milk yield without the concomitant increase in DM intake resulted in an increasing trend in feed efficiency with roasted soybean diet in experiment 1 (Table 2). Roasting had no effect on MUN concentration (Table 2), which suggests that the change in soybean protein degradability did not affect ruminal nitrogen availability and probably the absorption of metabolizable protein of microbial origin. However, in experiment 2,there was a reducing trend in the allantoin/creatinine ratio with roasted soybean treatment, which can be attributed to 
a small reduction in the amount of degradable protein available to the microorganisms in the rumen as a result of soybean roasting.

The apparent digestibility of DM, organic matter, and digestibility ofnon-NDF organic matter digestibility tended to decreasein the roasted soybean treatment (Table 3), which might suggest a limitation of microbial growth due to reduced protein ruminal degradation of this ingredient, especially when considered in conjunction with the reduction of allantoin/creatinine (Table 2) from the same treatment. However, as mentioned above, the MUN levels do not confirm this hypothesis. In addition, the digestibility of NDF is mostly affected bya limitation in microbial growth or activity, and this wasnot different among treatments (Table 3). Fecal nutrient analyses were not corrected for microbial contribution. Even though such contribution to DM and NDF is not as pronounced as it is to $\mathrm{CP}$ (which is why $\mathrm{CP}$ digestibility was not assessed), it still exists and might increase variation around these numbers.

The in situ rumen degradability test had a higher percentage of instantly degradable fraction (fraction A) in RAWthan in ROS. In contrast,an increase in fraction $\mathrm{B}$ was foundowing to heat treatment, but no differences in degradation rate in fraction $\mathrm{B}$ and fraction $\mathrm{C}$ between treatments were found (Table 3). Considering a solid passage rate of $6 \% / \mathrm{h}$ for both treatments,protein fractions and $\mathrm{kd}$ shown in table 3 and using the equation of NRC (2001), RAW presented an RUPof 50\% and a ROS of $59 \%$, which indicatedthat the roasting process was effective in reducing ruminal degradation protein without increasing fraction $\mathrm{C}$.

Since the treatments did not alter DMI, the contribution of endogenous protein to metabolizable protein flow is assumed to be the same between RAW and ROS. With that, by calculating the RUP values in the consumption of soybean in experiment 2 and assuming the same content of CP for both soybeans and $85 \%$ of intestinal digestibility of protein (NRC, 2001), the difference between the metabolizable protein from ROS and RAW is only 69 gday $^{-1}$. This difference is unlikely to explain increases in glucose availability or use of amino acids as an energy source in the mammary gland.It is important to emphasize that the $\mathrm{kd}$ values obtained in this experiment are much lower than the valuesreported in theNRC (2001) for RAW and ROS (10.9\%/hand $9.3 \% / \mathrm{h}$, respectively), which indicatedthat $69 \mathrm{~g}$ can potentially be overestimated. Therefore, the mechanism by which ROS increased production of lactose and milk solids may be related to the input of a specific amino acid that has a regulatory function in intramammary metabolism.

Table 3 - Apparent digestibility of nutrients in the total digestive tract of dairy cows fed with diets containing raw soybean (RAW) and roastedsoybean (ROS) (Experiment 2), and ruminal degradation kinetics of crude protein in RAW and ROS (degradability test).

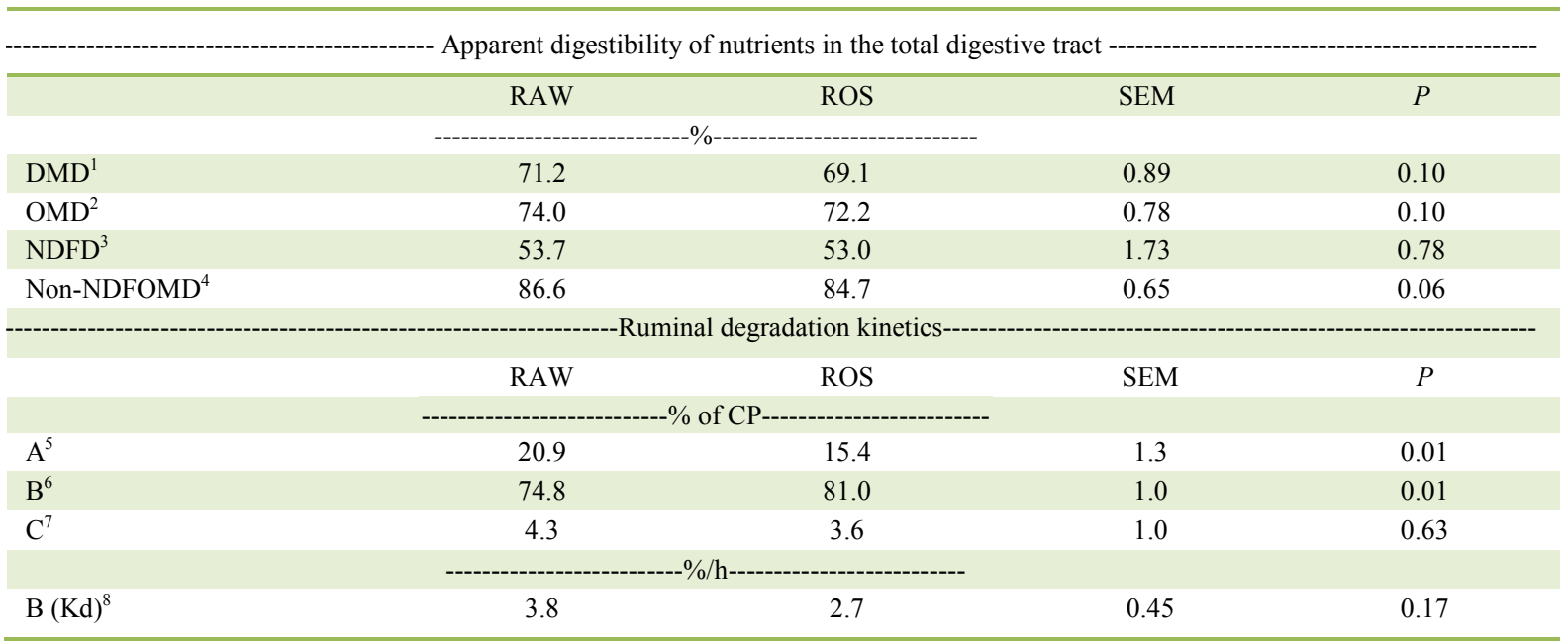

${ }^{1}$ Dry matter digestibility.${ }^{2}$ Organic matter digestibility. ${ }^{3}$ Neutral detergent fiber digestibility. ${ }^{4}$ Non-NDF organic matter digestibility. ${ }^{5} \mathrm{~A}=$ instantly degraded fraction. ${ }^{6} \mathrm{~B}=$ slowly degrades fraction. ${ }^{7} \mathrm{C}=$ indigestible fraction. ${ }^{8}$ Fractional degradation rate of fraction $\mathrm{B}$ with $\mathrm{r}^{2}$ was 0.89 for RAW and 0.91 for ROS. 


\section{CONCLUSION}

The replacement of RAW by ROS on both dietary inclusion levels tested resulted in an increased milk yield without affecting consumption and milk composition, which suggestedthat heat treatment was effective in increasing theflow of rumen undegradable amino acids of soy bean to the animal. The in situ degradability test showed that the roasting process was effective in reducing ruminal degradability of soybean protein.

\section{BIOETHICS AND BIOSSECURITY COMMITTEE APPROVAL}

The protocol was approved by the Universidade Federal de Lavras Bioethic Committee in Utilization of Animals (protocol no 040/2010)

\section{REFERENCES}

ABDI, E. et al. Effects of soybeans roasting and monensin on milk production and composition and milk fatty acids profile of lactating dairy cows. Livestock Science, v.153, p.73-80, 2013. Available from: $<$ http://www.sciencedirect.com/science/article/pii/ S1871141313000735>. Accessed: Jun. 15, 2016. doi: 10.1016/j. livsci.2013.01.018.

AMANLOU, H. et al.Effect of extruded and roasted soybeans on lactation performance and milk fatty acid profile of early lactating dairy cows. International Journal of Biosciences, v.2, n.10, p.11-18, 2012.Available from: $<$ http://www.openveterinaryjournal. com/2012/OVJ-075-06-12\%20H.\%20Amanlou\%20et\%20al.pdf>. Accessed: Jul. 02, 2015.

ASSOCIATION OF OFFICIAL ANALYTICAL CHEMISTS (AOAC). Official methods of analysisof the Association of Official Analytical Chemists.15.ed. Arlington, 1990. 1105p.

BERGMEYER, H.U. Methods of enzymatic analysis. Florida: VHC, 1985. 453p.

BOUTINAUD, $M$. et al. Milking and feed restriction regulate transcripts of mammary epithelial cells purified from milk. Journal of Dairy Science, v.91, p.988-998, 2008. Available from: <http://https://www.ncbi.nlm.nih.gov/ pubmed/18292254>. Accessed: Jun. 04, 2015. doi: 10.3168/ jds.2007-0587.

CHEN, X.B.; GOMES, M.J. Estimation of microbial protein supply to sheep and cattle based on urinary excretion of purine derivates - an overview of the technical details. Aberdeen: Rowett
Research Institute, International Feed Resources Unit, 1992. (Occasional Publication, p.1-21).

FALDET, M.A.; SATTER, L.D.Feeding heat-treated full fat soybeans to cows in early lactation. Journal of Dairy Science, v.74, n.9, p.3047-3054, 1991.Available from: <http://https://www. ncbi.nlm.nih.gov/pubmed/1779058>. Accessed: Jun. 12, 2015. doi: 10.3168/jds.S0022-0302(91)78490-7.

FATHI NASRI, M.H. et al.Past peak lactational performance of Iranian Holstein cows fed raw or roasted whole soybeanss. Journal of Animal Science, v.80, p.191-239, 2007. Available from: <http:// www.nrcresearchpress.com/doi/pdf/10.4141/CJAS07002>. Accessed: Jun. 22, 2016. doi: 1017/S0021859607007125.

FATHI NASRI, M.H. et al.Effect of heat processing on ruminal degradability and intestinal disappearance of nitrogen and amino acids in Iranian whole soybean. Livestock Science, v.113, p.43-51, 2008. Available from: <http://thescipub.com/PDF/ajavsp.2010.266.273. pdf $>$. Accessed: Jun. 02, 2016. doi: 10.3168/jds.2010-3978.

GALINDO, C.E. et al.Effect of amino acid or casein supply on whole-body, splanchnic, and mammary glucose kinetics in lactating dairy cows. Journal of Dairy Science.v.94, n.11, p.55585568, 2011. Available from: <http://www.journalofdairyscience. org/article/S0022-0302(11)00583-2/pdf>. Accessed: Jun. 07, 2016. doi: 10.3168/jds.2010-3978.

LEMOSQUET, S. et al. Effects of glucose, propionic acid, and nonessential amino acids on glucose metabolism and milk yield in Holstein dairy cows. Journal of Dairy Science, v.92, n.7, p.32443257, 2009a. Available from: <http://www.journalofdairyscience. org/article/S0022-0302(09)70641-1/pdf>. Accessed: Jun. 04, 2015.doi: $10.3168 /$ jds.2008-1610.

NATIONAL RESEARCH COUNCIL (NRC). Nutrient requirements of dairy cattle.7.ed. Washington, D.C: National Academy, 2001. 381p.

RAGGIO, G.S. et al.Effect of casein and propionate supply on mammary protein metabolism in lactating dairy cows. Journal of Dairy Science, v.89, n.11, p.4340-4351, 2006.Available from: $<$ http://https://www.ncbi.nlm.nih.gov/pubmed/17033022>. Accessed: Aug. 05, 2016. doi:10.3168/jds.S0022-0302(06)72481-X.

SALVATI, T.A. et al.Response of lactating cows to live yeast supplementation during summer. Journal of Dairy Science, v.98, p.4062-4073, 2015. Available from: <http://https://www.ncbi. nlm.nih.gov/pubmed/25795491>. Accessed: Nov. 27, 2016.doi: $10.3168 /$ jds.2014-9215

SCOTT, T.A. et al. Effects of roasting, extrusion, and particle size on the feeding value of soybeans for dairy cows. Journal of Dairy Science, v.74, p.2555-2562, 1991. Available from: <http://http:// www.sciencedirect.com/science/article/pii/S0022030291784336>. Accessed: May 18, 2016. doi: 10.3168/jds.S0022-0302(91)78433-6. 